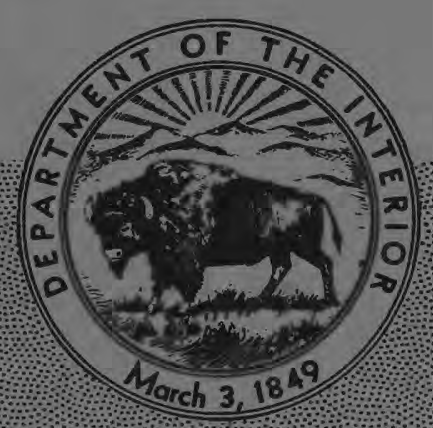

RESULTS OF RECONNAISSANCE

FOR RADIOACTIVE MINERALS IN

PARTS OF THE ALMA DISTRICT

PARK COUNTY, COLORADO 
UNITED STATES DEPARTMENT OF THE INTERIOR

Douglas McKay, Secretary

GEOLOGICAL SURVEY

W. E. Wrather, Director

GEOLOGICAL SURVEY CIRCULAR 294

\section{RESULTS OF RECONNAISSANCE FOR RADIOACTIVE MINERALS IN PARTS OF THE ALMA DISTRICT, PARK COUNTY, COLORADO}

By C. T. Pierson and Q. D. Singewald

This report concerns work done on behalf of the U. S. Atomic Energy

Commission and is published with the permission of the Commission. 


\title{
RESULTS OF RECONNAISSANCE FOR RADIOACTIVE MINERALS IN PARTS OF THE ALMA DISTRICT, PARK COUNTY, COLORADO
}

\author{
By C. T. Pierson and Q. D. Singewald
}

CONTENTS

Page

Page

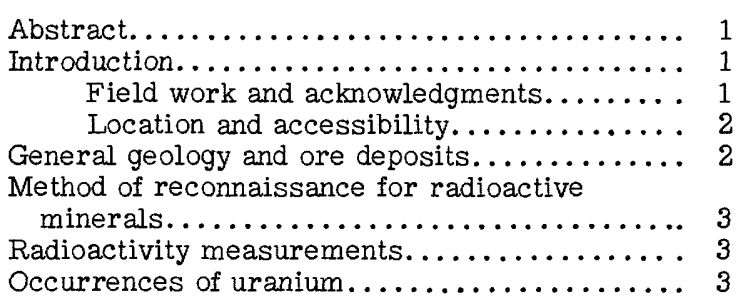

ILLUSTRATIONS
Occurrences of uranium-Continued

Veins in pre-Cambrian rocks......... 3

London vein system.............. 7

Veins east of Cooper Gulch fault......... 7

Disequilibria in the uranium occur-

rences................... 7

Nonradioactive localities............ 7

Origin..................... 7

Literature cited................... 9

Page

Plate 1. Generalized geologic map of the Alma district, Park County, Colo............... Inside back cover

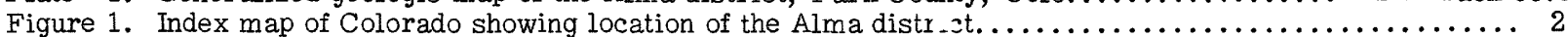

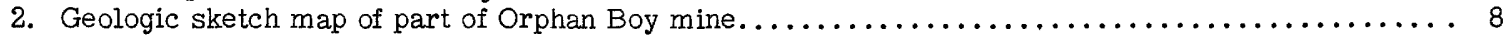

\section{TABLES}

Page

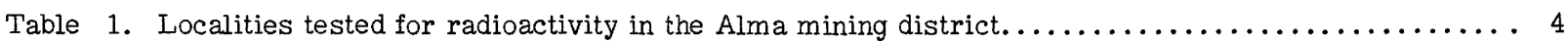

2. Relationship between ratio of maximum radioactivity measurements to average

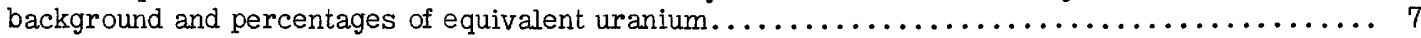

\section{ABSTRACT}

Pitchblende was discovered in July 1951 in the Alma mining district, Park County, Colo., by the U. S. Geological Survey acting on behalf of the U. S. Atomic Energy Commission.

The pitchblende is associated with Tertiary veins of three different geologic environments: (1) veins in preCambrian rocks, (2) the London vein system in the footwall block of the London fault, and (3) veins in a mineralized area east of the Cooper Gulch fault. Pitchblende is probably not associated with silver-lead replacement deposits in dolomite.

Secondary uranium minerals, as yet undetermined, are associated with pitchblende on two London vein system mine dumps and occur in oxidized vein material from dumps of mines in the other environments.

Although none of the known occurrences is of commercial importance, the Almadistrict is considered a moderately favorable area in which to prospect for uranium ore because 24 of the 43 localities examined show anomalous radioactivity; samples from anomalously radioactive localities, which include mine dumps and some underground workings, have uranium contents ranging from 0.001 to 1.66 percent.

\section{INTRODUCTION}

\section{Field work and acknowledgments}

A search for uranium in parts of the Alma mining district, Park County, Colo., was made during $2 \frac{1}{2}$ weeks of July and August 1951 by the U. S. Geological Survey on be half of the Atomic Energy Commission. Many mine dumps and mine workings were tested for radioactivity, and some were sampled, but time did not permit complete coverage even of the parts of the area examined.

V. R. Wilmarth and R. C. Vickers, of the Geological Survey, were members of the field party from July 16 through 19. L. R. Page, of the Geological Survey, and C. C. Towle, Jr., of the Atomic Energy Commission, visited the London Extension and South London mine areas on August 1. George Phair also of the Survey visited the areas and collected radioactive samples from London Extension and South London mine dumps on August 21, 1952.

Acknowledgements are due Mr. Joseph Thibodeau, foreman of the Buckskin Joe mine, and Mr. G. O. Lear at the Sweet Home mine for courtesies extended at the time these mines were examined. The writers are indebted to George Phair for providing the results of chemical and spectrographic analyses made from handpicked radioactive material. 


\section{Location and accessibility}

The Alma district (fig. 1) is located on the eastern slope of the Mosquito Range. The altitude of the area is from about 10,500 feet to more than 14,000 feet. Most of the localities examined can be reached by $a$. 4-wheel-drive vehicle.

\section{GENERAL GEOLOGY AND ORE DEPOSITS}

The geology of the Alma district has been described in several publications, to three of which the reader is particularly referred for details (Singewald and Butler, 1933, 1941; Singewald, 1947). The generalized geology of the Alma district, taken from plate 8 of Geological Survey Bulletin 955-D (Singewald, 1950), is shown on plate 1.

The bedrock of the Alma district is composed of (1) pre-Cambrian gneiss, schist, granite, and pegmatite; (2) pre-Pennsylvanian sedimentary strata, aggregating 300 to 600 feet in thickness and comprising the Sawatch quartzite and Peerless formation of Cambrian age, the
Manitou limestone of Ordivician age, the Chaffee formation (Devonian) including the Parting quartzite and Dyer dolomite members, and the Leadville dolomite of Mississippian age; (3) Pennsylvanian-Permian(?) sedimentary strata consisting of interbedded clastic rocks that range from coarse conglomerate to shale, with a few thin beds of dolomite; and (4) Tertiary(?) quartz monzonite porphyries, correlated with the White porphyry and the Gray porphyry group of Leadville, which occur mainly as sills in sedimentary strata or as dikes in preCambrian rocks. The Buckskin Gulch stock is composed of igneous rocks closely related to the porphyries.

Major structural features are shown on plate 1 . The regional dip of the strata is $10^{\circ}$ to $25^{\circ}$ east. Departures from this regional dip occur principally along folds associated with major faults.

There are two major faults in the district, each of which cuts the west limb of an anticline that is overturned to the west. The London fault is reverse, dips steeply northeastward, and has a throw of about 3,000 feet. The Cooper Gulch fault is reverse, dips $30^{\circ}$ eastward, and has a maximum throw of 450 feet at Mosquito Gulch.

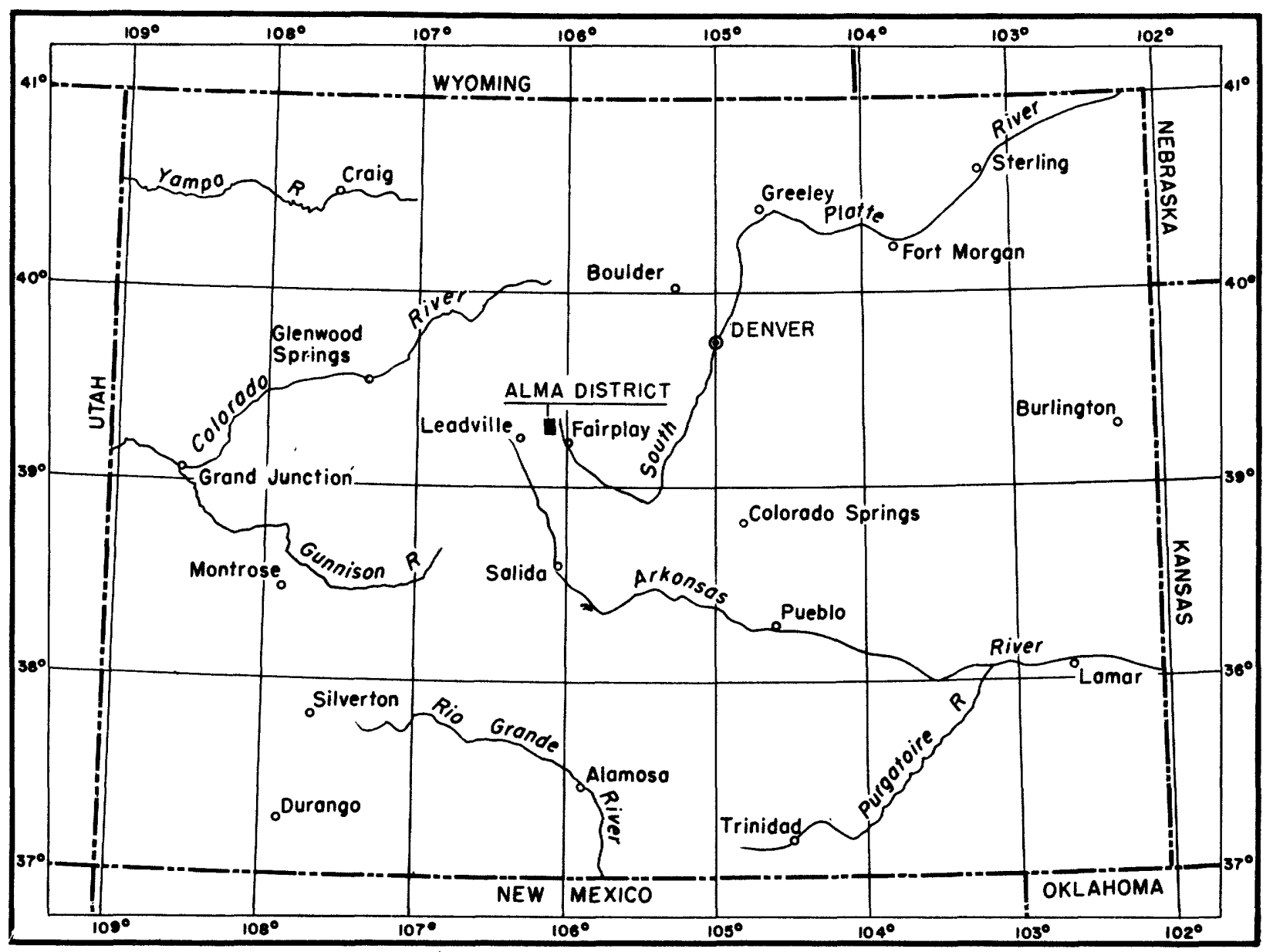

Figure 1. - Index map of Colorado showing location of the Alma district. 
The more important ore deposits, which for the most part are within the "mineralized areas" shown on plate 1, can be classified as follows: (1) Gold and silver veins in pre-Cambrian rocks, (2) gold-sulfide veins of the London type, (3) gold veins and replacement veins in Sawatch quartzite, and (4) silver-lead bedded replacement bodies and replacement veins in dolomites. Although mineralized fissures are abundant in the preCambrian rocks, commercial production from them has been limited to a few relatively small to medium-sized mines in Mosquito, Buckskin, and Platte Gulches.

The London vein system, in the footwall block of the London fault, consists of gold-bearing quartz-sulfide veins. Most of the ore occurred as veins within a zone of porphyry sills 175 to 275 feet thick, very close to the base of the Pennsylvanian system, but some were in veins in the upper part of the Leadville dolomite.

Most of the production from deposits in the Sawatch quartzite has been from mines in the mineralized areas east of the Cooper Gulch fault and on North Star Mountain. Veins along minor faults are productive at certain favorable horizons where thin ore shoots formed by replacement of the wall rock several feet outward from the faults. Beds containing conside rable quantities of carbonate cement, which was more easily replaced than the characteristic siliceous cement, localized most of the shoots.

The silver-lead production has come from bedded replacement bodies and replacement veins from (1) near the London fault at New York Mountain; (2) the Hock Hocking mine in the mineralized area east of the Cooper Gulch fault; and (3) the Mount Lincoln-Mount Bross area. Most of the ore occurred in the upper part of the Leadville dolomite.

\section{METHOD OF RECONNAISSANCE FOR RADIOACTIVE MINERALS}

Reconnaissance for radioactive minerals in the Alma district was carried out to test the uranium potentialities of the various types of geologic environment rather than to cover systematically all mine dumps and accessible mine workings in the district. The localities visited are shown on plate 1 ; the numbers refer to brief descriptions in table 1. For locations and descriptions of mines not visited, reference is made to the publications previously cited.

Forty-three localities were tested with Geiger counters, and 24 samples were taken. Sixteen grab samples were selected from mine dumps, and 8 were chip or chip-channel samples from underground exposures or prospect trenches.

\section{RADIOACTIVITY MEASUREMENTS}

Table 1 lists anomalous radioactivity measurements in milliroentgens per hour, taken with survey meters equipped with 6 -inch beta-gamma probes. Readings are not recorded for localities where no anomalous radioactivity was found. Locality numbers refer to plate 1, which shows all localities tested.

The maximum radioactivity measurements for a locality is the largest reading obtained by holding the probe directly against the surface of any specimen or underground exposure at the locality.
A locality or specimen is considered to be anomalously radioactive if the ratio of the maximum radioactivity measurement to the average background is equal to or greater than 1.7. The average background is taken, for convenience, as the arithmetic mean of the background measurement. Localities at which the ratio is less than 1.7 are not regarded as anomalously radioactive. The anomalously radioactive category has been divided into two classes: ratio of maximum radioactivity measurement to average background lies in the range 1.7 to 3.0 and ratio is greater than 3.0

With three exceptions out of 22 samples (table 2), the percentages of equivalent uranium obtained by laboratory analysis ranges from 0.004 to 0.008 in samples from localities at which the ratio of the maximum radioactivity measurement to average background is 1.7 to 3.0 , and more than 0.008 where the ratio is greater than 3.0. The percent equivalent uranium for localities at which the ratio is less than 1.7 doubtless is less than 0.004. Accordingly, the percent equivalent uranium may be roughly estimated for occurrences for which no laboratory analyses are available (e.g., locality 18). Ratios are not available for $31 \mathrm{~b}$ and $31 \mathrm{~d}$, but these occurrences have been assigned to the third group because of their relatively high uranium contents.

\section{OCCURRENCES OF URANIUM}

In the Alma district, uranium minerals are associated with Tertiary vein deposits of three different geologic environments: (1) veins in pre-Cambrian rocks; (2) veins of the London vein system; and (3) veins in a mineralized belt east of the Cooper Gulch fault. The known occurrences, although not of immediate cominercial importance, offer moderate encouragement for further search.

\section{Veins in pre-Cambrian rocks}

At localities 2 to $9,13,15$, to $18,20,21$ (pl. 1) veins or material from veins in the pre-Cambrian rocks of the Alma district were found to be anomalously radioactive. Localities 1,10 to 12,14 , and 19 show no abnormal radioactivity. Localities 11 and 12 are in quartz monzonites of Tertiary age intruded into pre-Cambrian rocks.

At the Kentucky Belle mine (8) disseminated pitchblende, not visible megascopically, occurs in the crushed rock of a 4-to 6 -inch-thick breccia zone in granite and pegmatite. Bad air about 400 feet from the portal precluded adequate examination of this zone. It also prevented any examination for radioactivity of the ground from which most of the ore was obtained; that is, within and near a White porphyry dike which apparently was cut by the adit less than 1, 000 feet from the portal. A sample from the dump of a nearby caved adit (3) contains pitchblende and pyrite in a narrow vein that cuts granite. As much as 0.013 percent uranium is contained in pyritic siliceous vein material from the Champaign fissure (20). Radon was detected in the Sweet Home mine (13).

No secondary uranium minerals have been determined, but one or more are probably present in such oxidized samples as $8 \mathrm{a}$ and 21 . 


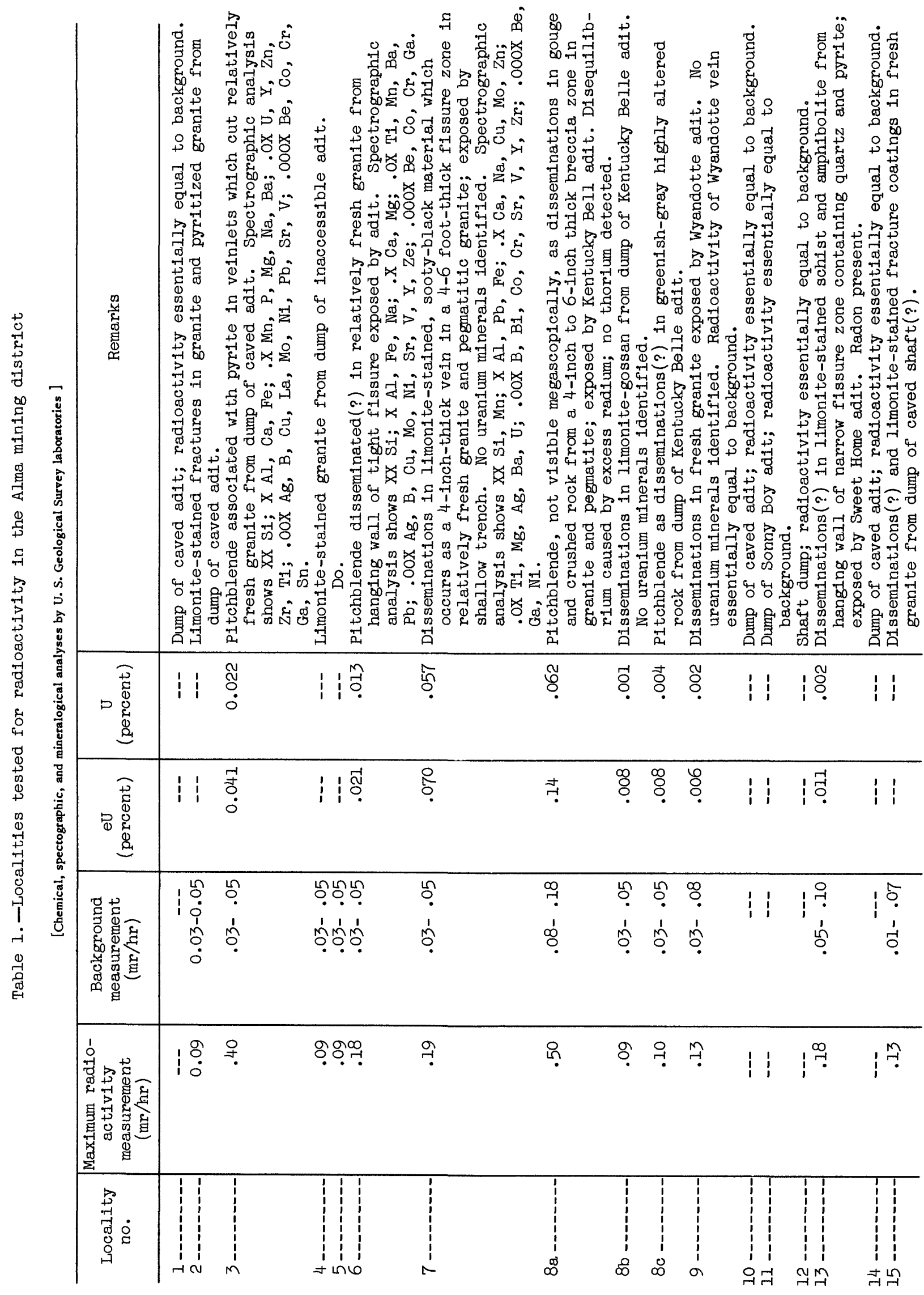




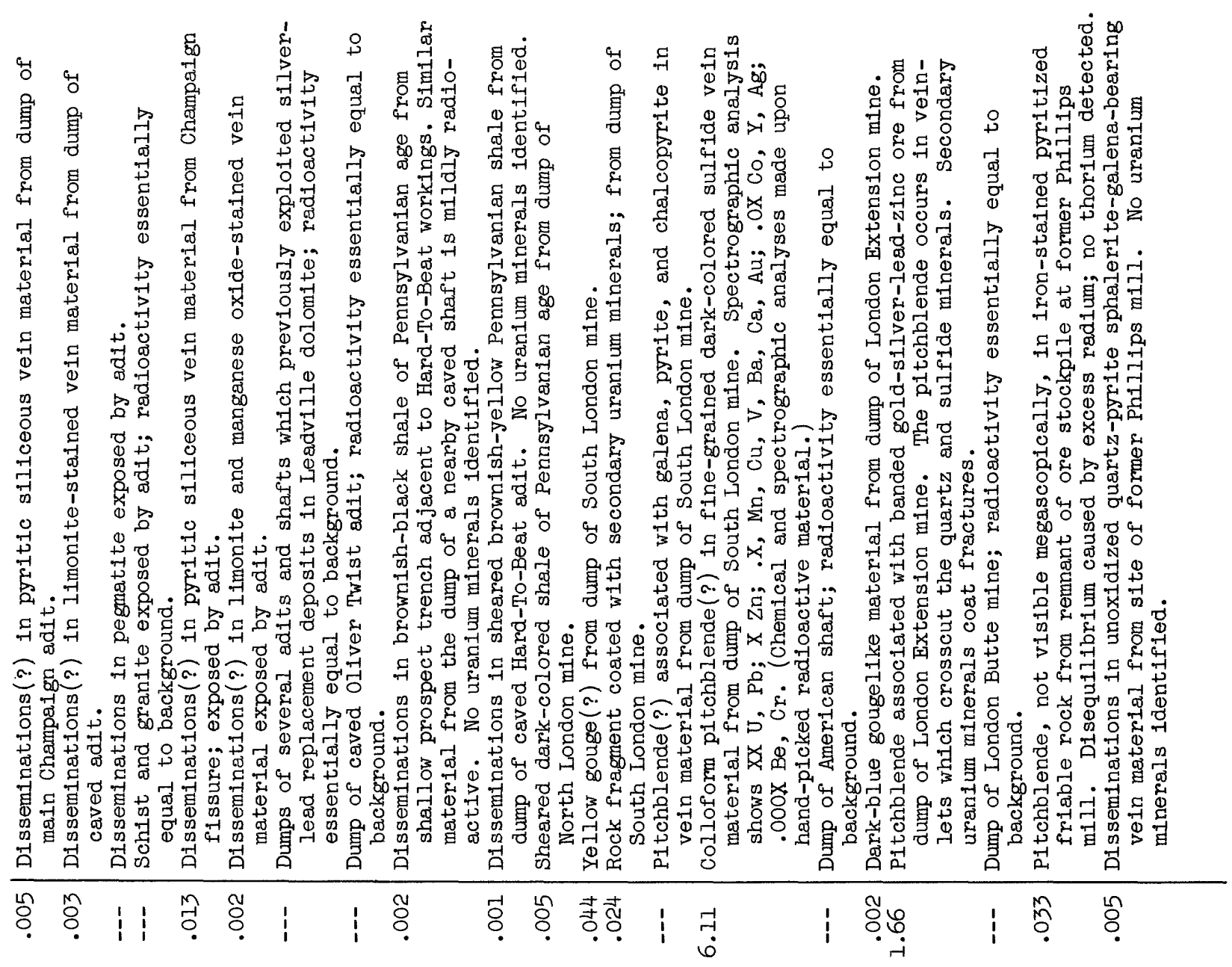

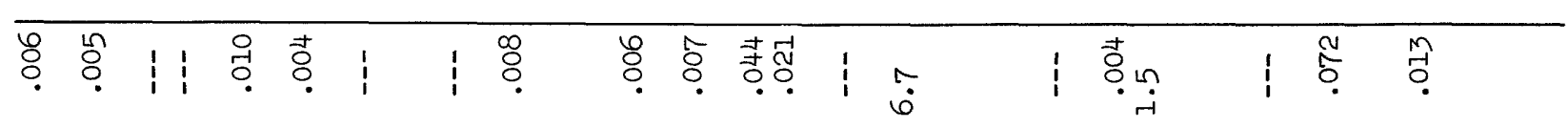

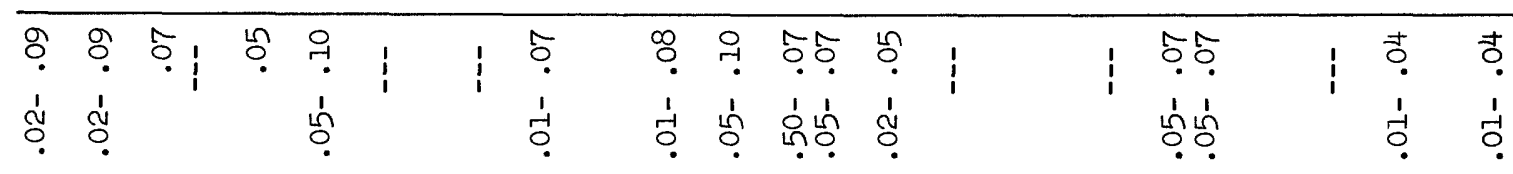

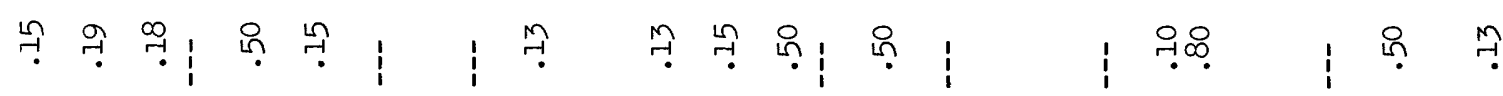

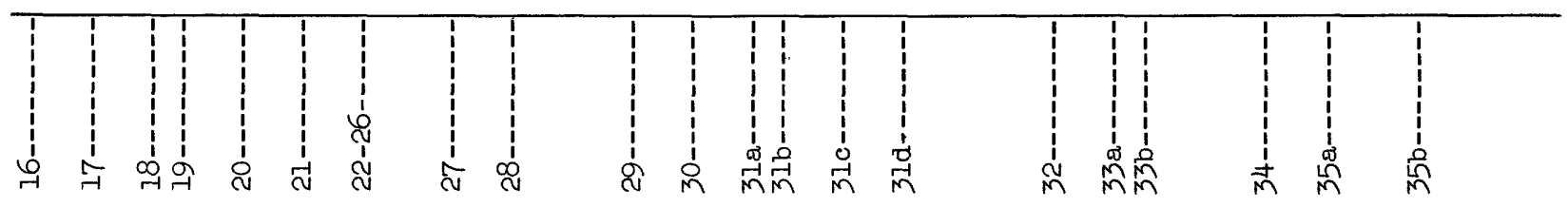




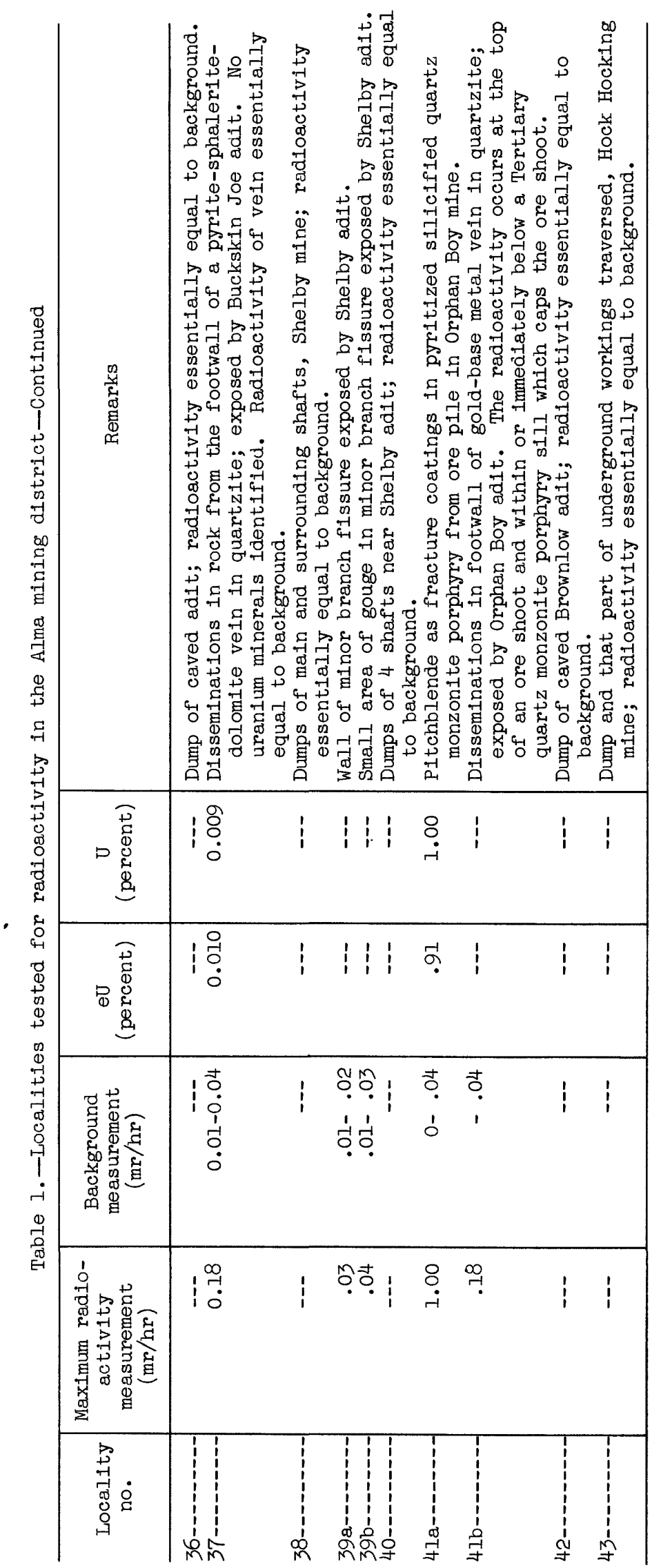


Table 2.-Relationship between ratio of maximum radioactivity measurements to average background and percentages of equivalent uranium ${ }^{1}$

\begin{tabular}{c|c|r|r}
\hline $\begin{array}{c}\text { Range of } \\
\text { ratios }\end{array}$ & Symbol used for plate 1 & $\begin{array}{c}\text { Number of } \\
\text { localities or } \\
\text { occurrences }\end{array}$ & $\begin{array}{c}\text { Percent equivalent } \\
\text { uranium for analyzed } \\
\text { specimens }\end{array}$ \\
\hline $1.7-3.0$ & Cross-in-square- & 9 & 2 \\
$3.1-50.0$ & Solid square-0.004-0.008 \\
\hline
\end{tabular}

${ }^{1}$ Percent equivalent uranium has not been determined for the 19 localities at which the ratios are less than 1.7 , nor for 9 occurrences for which the ratios are equal to or gteater than 1.7. Ratios are not available for 2 occurrences for which percent equivalent uranium has been determined.

${ }^{2}$ Except for locality 13 (0.011 percent) where radon in adit caused ratio of maximum radioactivity measurement to background to be exceptionally low.

${ }^{3}$ Except for localities $17(0.005$ percent $)$ and 28 (0.008 percent).

Many small mines and prospects along veins in pre-Cambrian rocks of the Platte, Buckskin, and Mosquito Gulches were not examined for radioactivity in 1951; so further investigation of possibilities within pre-Cambrian terrane may be justified.

\section{London vein system}

Anomalously radioactive material from the dumps of mines along the London vein system was found at localities 28 to 31 , and 33 but not at localities 27 , 32 , and 34 (pl. 1).

Slightly radioactive gougelike material, as well as specimens that contain pitchblende associated with banded gold-silver-lead-zinc ores, was found on the dump of the now inoperative London Extension mine (33). The hard lustrous pitchblende occurs in veinlets that crosscut the quartz and sulfide minerals. Secondary uranium minerals coat fractures in these specimens. Pitchblende associated with sulfide vein material, and secondary(?) uranium minerals associated with yellow gouge(?) were found on the dump of the South London mine (31).

Slightly radioactive shale, presumably from the lowermost 150 feet of the Pennsylvanian system, was found on dumps and in a prospect trench at the HardTo-Beat mine and vicinity $(28,29)$. It probably came from a shear zone in the west wall of the London fault. Some Pennsylvanian shale on the dump of the North London mine $(30)$ is mildly radioactive.

\section{Veins east of Cooper Gulch fault}

In the mineralized area east of the Cooper Gulch fault, veins or vein material from localities $35,37,39$ and 41 (pl. 1) show anomalous radioactivity. Localities 36 , $38,40,42$, and 43 are not anomalously radioactive.

At the Orphan Boy mine (41; and fig. 2) anomalous radioactivity, probably caused by pitchblende, was detected in the footwall of the gold-base-metal vein in Sawatch quartzite of Cambrian age. The radioactivity occurs at the top of an ore shoot (41b), and within or immediately below a Tertiary quartz monzonite porphyry sill that caps the ore shoot. A sample of pyritized and silicified quartz monzonite porphyry (41a) from an ore pile in this mine contains pitchblende as fracture coatings.

In the Buckskin Joe mine (37) a sample from the footwall of a pyrite-sphalerite-dolomite vein in Sawatch quartzite contains 0.009 percent uranium, but the other parts of the vein are not anomalously radioactive.

Other localities at which anomalous radioactivity was noted are a remnant of an ore stockpile at the former Phillips mill (35) and the underground workings of the Shelby mine (39).

\section{Disequilibria in the uranium occurrences}

Inspection of the laboratory analyses for uranium and equivalent uranium (table 1) shows that the ratio of percent uranium to percent equivalent uranium in samples from the Alma district ranges from a minimum of 0.13 (locality $8 \mathrm{~b}, \mathrm{pl} .1$ ) to a maximum of $1.30(20)$. The ratio is equal to or less than 1.00 in 20 of the 24 analyses.

Two of the samples (8a, 35a), which exhibit ratios of less than 0.50, were analyzed for radium and thorium contents. No thorium was detected, and radium and other daughter products of uranium are in excess of the uranium present in the samples. It is probable that the disequilibria in all or most of the samples where the ratios are less than 1.0 have been caused by removal of uranium by supergene processes.

The four causes where the ratio is greater than 1.0 probably resulted from the combination of analytical errors and loss of radon during sample grinding.

\section{Nonradioactive localities}

Some nonradioactive localities, previously listed, have been found in each of the three geologic environments discussed. Silver-lead replacement deposits in dolomite, where tested for radioactivity at New York Mountain (localities 22, 26, pl. 1) and at the Hock Hocking mine (43), were not anomalously radioactive. The silver-lead dolomite replacements of the Mount Lincoln-Mount Bross area have not been tested.

\section{Origin}

Because of the close association of the pitchblende with the base- and precious-metal veins of Tertiary age, the writers believe that the pitchblende of the Alma district was deposited by hypogene processes. The secondary uranium minerals resulted from supergene alteration of the primary pitchblende. 


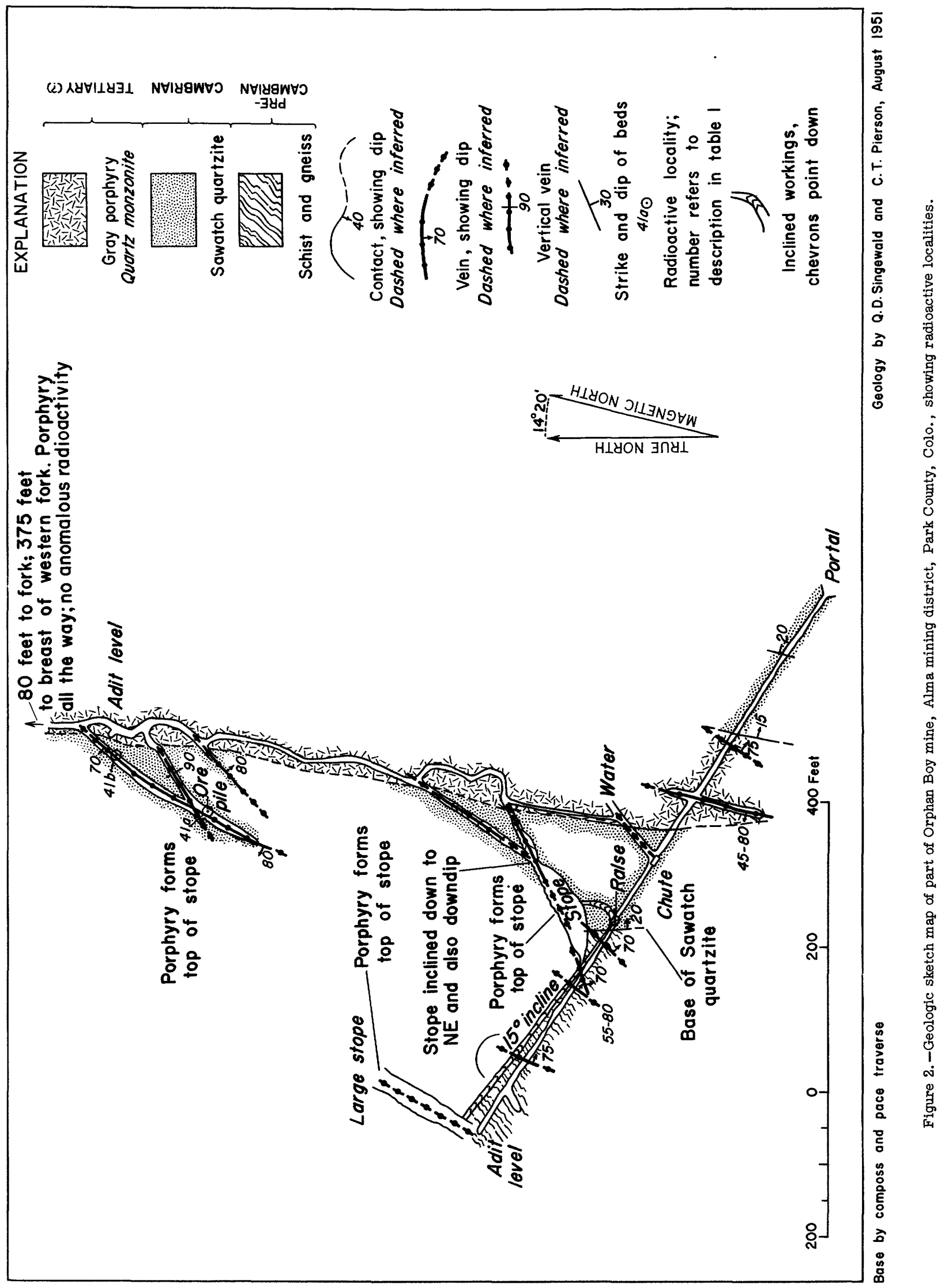




\section{LITERATURE CITED}

Singewald, Q. D., 1947, Lode deposits of Alma and Horseshoe districts, Park County, Colo., in Vanderwilt, J. W. , ed., Mineral resources of Colorado, p. 336-341: Colo. Min. Res. Board. 1950, Gold placers and their geologic environment in northwestern Park County, Colo.: U. S. Geol. Survéy Bull. 955-D, p. 103-172.
Singewald, Q. D., and Butler, B. S., 1933, Suggestions for prospecting in the Alma district, Colo.: Colo. Sci. Soc. Proc., v. 13, no. 4, p. 89-131. 1941, Ore deposits in the vicinity of the London fault of Colorado: U. S. Geol. Survey Bull. 911. 


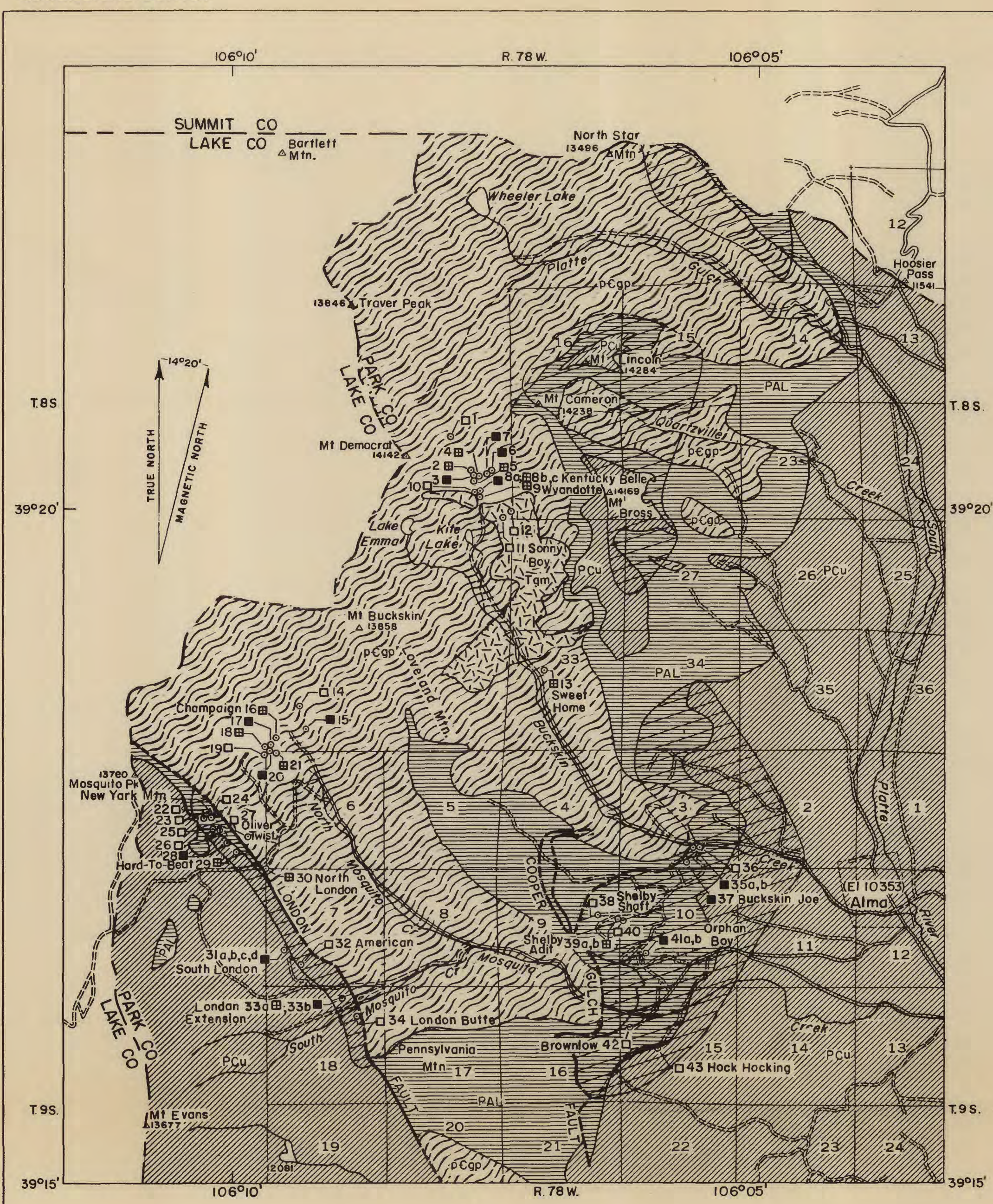

EXPLANATION

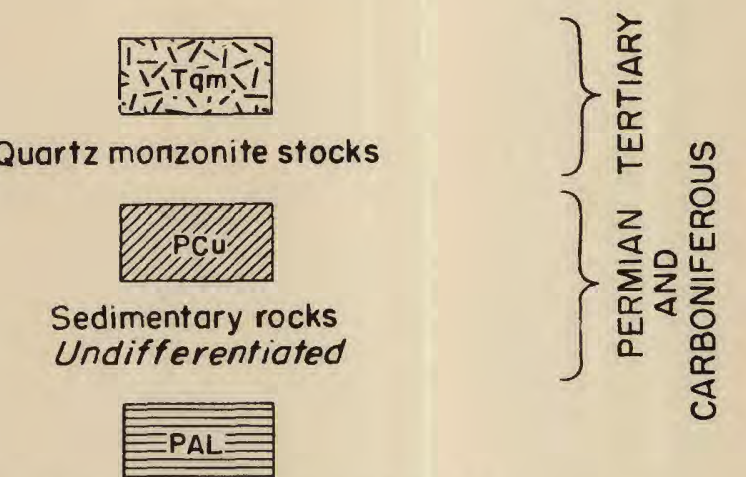

Pre-Pennsylvanian sedimentary rocks

$$
\text { popicin }
$$

Schist-injection gneiss series Whitish-gray granite and pegmatite

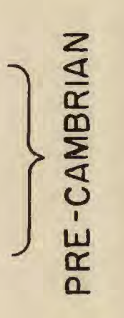

Dashed where approximately located

$$
\text { Major fault }
$$

Dashed where approximately located

$$
\sum_{\text {Mineralized area }}
$$

Note: Early Tertiary intrusive porphyries occur abundantly as sills, dikes and laccoliths in all formations.

Mine, mine dump, or prospect pit tested for radioactivity Number refers to description in table

\section{MAXIMUM RADIOACTIVITY}

$\square$

Less than 1.7 times average background $\boxplus$

$1.7-3$ times overage background

-

Greater than 3 times overage background

GENERALIZED GEOLOGIC MAP OF THE ALMA DISTRICT, PARK COUNTY, COLORADO, SHOWING AREAS TESTED FOR RADIOACTIVITY

$\underbrace{5000,1,1,1}_{\text {Datum is mean sea level }}$

